九州大学学術情報リポジトリ

Kyushu University Institutional Repository

\title{
Inactivation of Bacillus stearothermophilus and Bacillus coagulans spores as indicators of sterilization by reciprocal pressurization
}

Furukawa, Soichi

Laboratory of Food Process Engineering, Department of Bioresource and Bioenvironment Sciences, Graduate School, Kyushu University

Saita, Koji

Laboratory of Food Process Engineering, Department of Food Science and Technology, Faculty of Agriculture, Kyushu University

Kato, Tatuo

Department of Bioscience and Biotechnology, Faculty of Agriculture, Kyushu University

Shimoda, Mitsuya

Department of Bioscience and Biotechnology, Faculty of Agriculture, Kyushu University

他

https://doi.org/10.5109/24368

出版情報：九州大学大学院農学研究院紀要. 45（1)，pp. 183-188，2000-11. Kyushu University バージョン：

権利関係: 


\title{
Inactivation of Bacillus stearothermophilus and Bacillus coagulans spores as indicators of sterilization by reciprocal pressurization
}

\author{
Soichi Furukawa*, Koji Saita**, Tatuo Kato***, \\ Mitsuya Shimoda*** and Isao Hayakawa*** \\ Laboratory of Food Process Engineering, Division of Food Biotechnology, \\ Department of Bioscience and Biotechnology, Faculty of Agriculture, \\ Kyushu University, Fukuoka 812-8581, Japan \\ (Received July 7, 2000 and accept August 18, 2000)
}

\begin{abstract}
The effects of the reciprocal pressurization (six reciprocal cycles of $5 \mathrm{~min}$ pressurization) (RP) and the continuous pressurization (30-min pressurization) (CP) on the inactivation of spores of Bacillus coagulans and Bacillus stearothermophilus were studied. The combined parameters used were hydrostatic pressure $(100,200,300$ and $400 \mathrm{MPa})$, temperature $(45,55$, 65 and $75^{\circ} \mathrm{C}$ ) and total pressurization period $(30 \mathrm{~min})$. RP was more effective than CP on inactivating bacterial spores. However, the effectiveness of RP on increasing the inactivation power was observed in hydrostatic pressure over $200 \mathrm{MPa}$.
\end{abstract}

\section{INTRODUCTION}

Dormant bacterial spores are highly resistant to many physical and chemical conditions including heat, drying, radiation and chemicals such as hydrogen peroxide (Gould 1983), and their inactivation is the main objective of food sterilization. Heat, radiation and chemical preservatives are the major means for the sterilization (Russell 1991). Of these methods, moist heat sterilization is the most commonly used (Walker \& LaGrange 1991). However, the heat sterilization usually results in detrimental changes in the nutritive value, color and flavor of foods (Joslyn 1991).

On the other hand, high hydrostatic pressure can inactivate microorganisms without altering the flavor and nutrient components in foods (Cheftel 1992). Hence, major investigations are currently focussed on the potentials of hydrostatic pressure treatments as an alternative to heat treatments (Hoover et al. 1989). The effects of hydrostatic pressure treatments on the destruction of microorganisms were reported 100 years ago (Hite 1899), and the application of such technology to food processing has increased in the past decade (Hayashi 1992). In hydrostatic pressure sterilization, bacterial spores were more resistant than vegetative bacteria (Timson \& Short 1965; Cheftel 1992), surviving up to $1200 \mathrm{MPa}$ (Larson et al. 1918; Johnson and ZoBell 1949; Timson and Short 1965; Sale et al. 1970). Hence, it has been suggested that bacterial spores are poorly sterilized by the hydrostatic pressure treatment at room temperature (Sale et al. 1970).

* Laboratory of Food Process Engineering, Department of Bioresource and Bioenvironment Sciences, Graduate School, Kyushu University

** Laboratory of Food Process Engineering, Department of Food Science and Technology, Faculty of Agriculture, Kyushu University

*** Department of Bioscience and Biotechnology, Faculty of Agriculture, Kyushu University

* Corresponding author (E-mail: souichi@agr.kyushu-u.ac.jp) 
Therefore, the sterilizing effects of hydrostatic pressure on bacterial spores in a combination with heat (Gould 1973; Mallidis \& Drizou 1991; Okazaki et al. 1994; Roberts \& Hoover 1996), irradiation (Crawford et al. 1996), low pH (Roberts \& Hoover 1996) and bacteriocins such as nisin (Roberts \& Hoover 1996) have been studied.

We have been studying the impulsive force generated by quick decompression and its effect on the inactivation of bacterial spores (Hayakawa et al. 1998). From this work, we considered that the reciprocal compression and decompression of hydrostatic pressure could increase the injury and inactivation power on bacterial spores comparing to a continuous pressurization.

In the present paper, we report the effect of the reciprocal pressurization (RP) on the inactivation of bacterial spores of Bacillus coagulans and B. stearothermophilus and the comparison of its inactivation effect with continuous pressurization (CP).

The spore of $B$. stearothermophilus is the most heat-tolerant species among aerobic spore-forming bacteria. This microorganism is often used as a biological indicator to evaluate sterilization processes because of its high heat resistance (López et al. 1997; Periago et al. 1998).

\section{MATERIALS AND METHODS}

\section{Bacterium}

The bacteria used were Bacillus coagulans IFO12583 and Bacillus stearothermophilus IFO12550, obtained from the Institute for Fermentation Osaka (Osaka, Japan).

\section{Media and culture conditions}

Log-phase-cultures of $B$. coagulans and B. stearothermophilus grown in nutrient broth (Eiken Chemical Co., Ltd., Tokyo, Japan) were transferred to soil-infusion-agar-plates (Berry \& Brandshaw 1980), which consisted of nutrient agar (Eiken Chemical Co., Ltd., Tokyo, Japan) plus a soil extract. The plates were incubated at $37^{\circ} \mathrm{C}$ (B. coagulans) and $55^{\circ} \mathrm{C}$ (B. stearothermophilus) for 10 days.

\section{Preparation of spore suspensions}

Spores were collected by flooding the surface of the culture with sterile distilled water, and then scraping the surface with a sterile microscope glass slide. After collecting, the spores were washed three times by centrifugation at $4,000 \times \mathrm{g}$ for $30 \mathrm{~min}$, and resuspended in sterile distilled water and stored at $4{ }^{\circ} \mathrm{C}$ until use. The spore suspensions were diluted to give approximately $10^{6}$ colony forming units (CFU) $\mathrm{ml}^{-1}$.

\section{Pressure treatment}

Spore suspensions were sealed in $1.5 \mathrm{ml}$ portions in sterile screw-capped plastic tubes ( $1.5 \mathrm{ml}$ capacity; Greiner Labortechnik Co., Ltd., Germany), and these tubes were pressurized. The equipment used was a prototype pressurization apparatus (Hayakawa et al. 1994). The time needed to achieve the treatment pressure was between 10 and $30 \mathrm{~s}$, depending on the required pressure. The decompression time was less than $1 \mathrm{~s}$. The temperature of the pressure cell was regulated by a thermocontrolled water bath (Haake GH, Germany). Several combinations of hydrostatic pressure (100, 200, 300 and 
$400 \mathrm{MPa})$, temperature $\left(45,55,65\right.$ and $\left.75^{\circ} \mathrm{C}\right)$, total holding period $(30 \mathrm{~min})$ and reciprocal time ( 1 and 6 ) were used in this study.

\section{Measurement of survivors}

The number of survivors was determined by the viable count method using a nutrient agar. The plates were incubated at $37^{\circ} \mathrm{C}\left(B\right.$. coagulans) and $55^{\circ} \mathrm{C}(B$. stearothermophilus) for $24 \mathrm{~h}$ and then enumerated.

\section{Statistical analysis}

All experiments were done in triplicate. The data presented are the means of three replicate experiments. Significant differences between the RP and the CP treatment were determined by Student's t test $(\mathrm{P}<0.05)$.
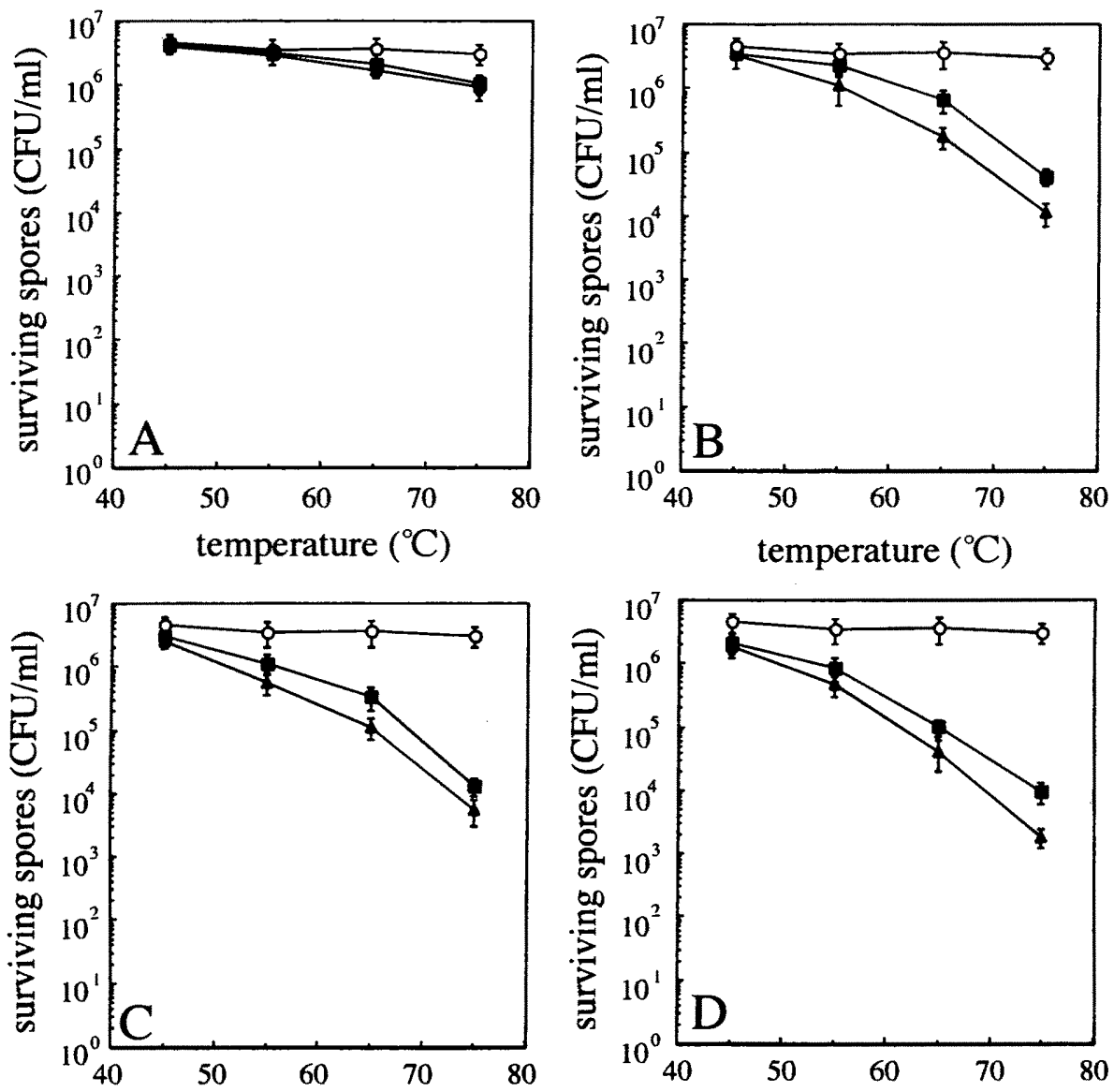

Fig. 1. Effect of the treatment temperature on the inactivation of Bacillus coagulans IFO12583 spores by the CP ( $\boldsymbol{\square}$ ) and the RP treatment (A) at (A) 100, (B) 200, (C) 300 and (D) $400 \mathrm{MPa}$ or $30 \mathrm{~min}$ in distilled water. The symbol, $\mathrm{O}$, shows the control experiment $(0.1 \mathrm{MPa})$. 


\section{RESULTS AND DISCUSSION}

The number of spores inactivated by RP was more than that of spores by $\mathrm{CP}$ at pressure ranging from 100 to $400 \mathrm{MPa}$. There was no significant difference $(\mathrm{P}<0.05)$ between the RP and the CP treatment on the inactivation of $B$. coagulans spores at $100 \mathrm{MPa}$ (Fig. 1A), but there was significant difference $(\mathrm{P}<0.05)$ at $200 \mathrm{MPa}$ except for $45^{\circ} \mathrm{C}$ and $55^{\circ} \mathrm{C}$ (Fig. 1B), at $300 \mathrm{MPa}$ except on for $45^{\circ} \mathrm{C}$ and $55^{\circ} \mathrm{C}$ (Fig. $1 \mathrm{C}$ ), and at $400 \mathrm{MPa}$ except for $45^{\circ} \mathrm{C}$ and $55^{\circ} \mathrm{C}$ (Fig. 1D). There was no significant difference $(\mathrm{P}<$ 0.05 ) between the $\mathrm{RP}$ and the $\mathrm{CP}$ treatment on the inactivation of $B$. stearothermophilus
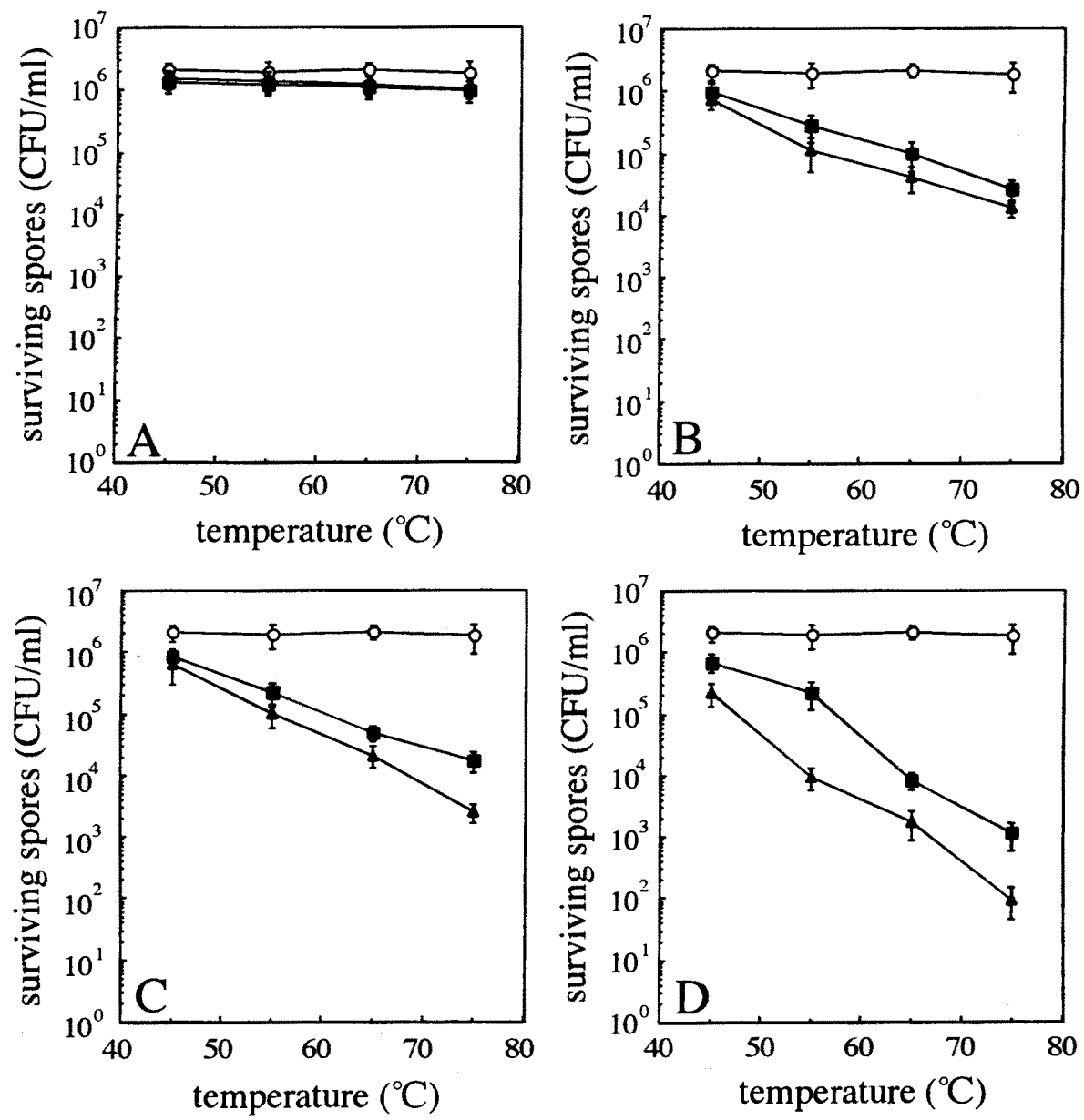

Fig. 2. Effect of the treatment temperature on the inactivation of Bacillus stearothermophilus IFO12550 spores by the CP ( $)$ and the RP treatment (A) at (A) 100, (B) 200, (C) 300 and (D) $400 \mathrm{MPa}$ or $30 \mathrm{~min}$ in distilled water. The symbol, $\mathrm{O}$, shows the control experiment $(0.1 \mathrm{MPa})$. 
spores at 100 and $200 \mathrm{MPa}$ (Fig. $2 \mathrm{~A}$ and $\mathrm{B})$, but there was significant difference $(\mathrm{P}<0.05)$ at $300 \mathrm{MPa}$ except for $45^{\circ} \mathrm{C}$ and $55^{\circ} \mathrm{C}$ (Fig. 2C), and at $400 \mathrm{MPa}$ (Fig. 2D). These results showed that RP was more effective in inactivating bacterial spores than $\mathrm{CP}$. However, the effectiveness of $\mathrm{RP}$ on increasing the inactivation power was observed in hydrostatic pressure at least above $200 \mathrm{MPa}$.

With B. stearothermophilus spores, about 4-log-cycles inactivation was observed at $75^{\circ} \mathrm{C}, 400 \mathrm{MPa}$ (Fig. 2D). However, with $B$. coagulans spores, about only 3 -log-cycles inactivation was observed at $75^{\circ} \mathrm{C}, 400 \mathrm{MPa}$ (Fig. 1D). These results showed that $B$. coagulans spores were more resistant to the CP and RP treatment, although $B$. coagulans spores were more heat sensitive than $B$. stearothermophilus spores (Shibasaki 1998). B. coagulans spores could be inactivated easily than B. stearothermophilus spores in combination with more intensive heat treatment.

The RP treatment was able to decrease the processing temperature and pressure needed to inactivate bacterial spores. Lowering the processing temperature can decrease heat damages of processed foods. From the viewpoint of reducing the cost of high pressure equipment (Kanda et al. 1992), decreasing the processing pressure is the most important point in the application of hydrostatic pressure treatment to food sterilization.

\section{ACKNOWLEDGMENT}

A part of this research was supported by grant of Scientific Research Fund from the Ministry of Education, Science, Sports and Culture.

\section{REFERENCES}

Berry, M. R., Jr. and J. G. Brandshaw 1980 Heating characteristics of condensed cream of celery soup in a steritort: heat penetration and spore count reduction. J. Food Sci., 45: 869-879

Cheftel, J. C. 1992 Effects of high hydrostatic pressure on food constituents: an overview. In "High Pressure Biotechnology", ed. by C. Balny, R. Hayashi, K. Heremans and P. Masson, Colloque INSERM/John Libbey and Co., Ltd. London, pp. 195-209

Crawford, Y. J., E. A. Murano, D. G. Olson and Shenoy, K. 1996 Use of high hydrostatic pressure and irradiation to eliminate Clostridium sporogenes spores in chickenbreast. J. Food Prot., 59: 711-715

Gould, G. W. 1973 Inactivation of spores in food by combined heat and hydrostatic pressure. Acta Aliment., 2: 377-383

Gould, G. W. 1993 Mechanisms of resistance and dormancy. In "Disinfection, sterilization, and preservation", Vol. 4, ed. by A. Hurst and G. W. Gould, Academic Press Inc., New York, pp. 173-209

Hayakawa, I., S. Furukawa, A. Mizunaga, H. Horiuchi, T. Nakashima, Y. Fujio, Y. Yano, T. Ishikura and K. Sasaki 1998 Mechanism of inactivation of heat-tolerant spores of Bacillus stearothermophilus IFO12550 by rapid decompression. J. Food Sci, 63: 371-374

Hayakawa, I., T. Kanno, M. Tomita and Y. Fujio 1994 Application of high pressure for inactivation and protein denaturation. J. Food Sci., 59: 159-163

Hayashi, R. 1992 Utilization of pressure in addition to temperature in food science and technology. In "High Pressure Biotechnology", ed. by C. Balny, R. Hayashi, K. Heremans and P. Masson, Colloque INSERM/John Libbey and Co., Ltd. London, pp. 185-193

Hite, B. H. 1899 The effect of pressure in the preservation of milk, Bulletin, 58: 15-35, Morgantown: West Virginia University of Agriculture Experimental Station

Hoover, D. G., C. Metrick, A. M. Papineau, D. F. Farkas and D. Knorr 1989 Biological Effects of High Hydrostatic Pressure on Food Microorganisms. Food Tech., 43: 99-107

Johnson, F. H., and C. E. ZoBell 1949 The retardation of thermal disinfection of Bacillus subtilis spores 
by hydrostatic pressure. J. Bacteriol., 57: 353-358

Joslyn L. J. 1991 Sterilization by heat. In "Disinfection, sterilization, and preservation", ed. by S. S. Block, Lea \& Febiger, London, pp. 495-526

Kanda, T., T. Yamauchi, T. Naoi, and Y. Inoue 1992 Present status and future prospects of high pressure food processing equipment. In "High Pressure Biotechnology", ed. by C. Balny, R. Hayashi, K. Heremans and P. Masson, Colloque INSERM/John Libbey and Co., Ltd. London, pp. 521-524

Larson W. P., T. B. Hartzell and H. S. Diehl 1918 The effect of high pressure on bacteria. J. Infect. Dise., 22: $271-279$

López, M., I. González, M. Mazas, J. González, R. Martin and A. Bernardo 1997 Influence of recovery conditions on apparent resistance of Bacillus stearothermophilus spores. Int. J. Food Sci. \& Tech., 32: 305-311

Lund, D. B. 1977 Design of thermal processes for maximizing nutrient retention. Food Tech., 31(2): $71-78$

Mallidis, C. G. and D. Drizou 1991 Effect of simultaneous application of heat and pressure on the survival of bacterial spores. J. Appl. Bacteriol., 71: 285-288

Okazaki, T., T. Yoneda and K. Suzuki 1994 Combined effects of temperature and pressure on sterilization of Bacillus subtilis spores. J. Jap. Soc. for Food Sci. and Tech., (in Japanese) 41 : 536-541

Periago, P. M., P. S. Fernández, M. J. Ocio and A. Martínez 1998 Apparent thermal resistance of Bacillus stearothermophilus spores recovered under anaerobic conditions. $Z$ Lebensm. Unt. For. A, 206: 63-67

Roberts, C. M., and D. G. Hoover 1996 Sensitivity of Bacillus coagulans spores to combinations of high hydrostatic pressure, heat, acidity and nisin. J. Appl. Bacteriol., 81: 363-368

Russell A. D. 1991 Principles of antimicrobial activity. In "Disinfection, sterilization, and preservation", ed. by S. S. Block, Lea \& Febiger, London, pp. 29-58

Sale, J. H., G. W. Gould and W. A. Hamilton 1970 Inactivation of bacteria spores by hydrostatic pressure. J. Gen. Microbiol., 60: 323-334

Shibasaki, I. 1998 Heat sterilization. In "New Technology of Food Sterilization", ed. by I. Shibasaki, Korin Co., Tokyo, pp. 10-11

Timson, W. J., \& A. J. Short 1965 Resistance of microorganisms to hydrostatic pressure. Biotechnol. and bioengin., 7: 139-159

Walker L. J. and W. S. LaGrange 1991 Sanitation in food manufacturing operations. In "Disinfection, sterilization, and preservation", ed. by S. S. Block, Lea \& Febiger, London, pp. 791-801 